\title{
Alternate Strip Clearcutting in Upland Black Spruce II. Factors Affecting Regeneration in First-cut Strips
}

\author{
by
}

\author{
John K. Jeglum ${ }^{1}$
}

\section{Abstract}

In a two-cut, alternate strip clearcutting system in upland black spruce, the main factors influencing black spruce regeneration in the first-cut strips were strip width, natural seeding period, amount of receptive seedbed and topographic position. In the three study areas, $80-\mathrm{m}$ strips yielded over $60 \%$ stocking and over 7500 seedlings per hectare with a 4year natural seeding period. Narrower strips $40 \mathrm{~m}$ and $20 \mathrm{~m}$ wide showed increasing levels of reproduction. Four years of natural seeding gave better natural regeneration than two years. Seedling density and frequency in quadrats were correlated with the amount of receptive seedbed. Regeneration was more abundant on drainageways and lower slopes, and less abundant on upper slope and crest sites. For successful regeneration under similar climatic and physiographic conditions, strip widths should be no more than $80 \mathrm{~m}$, and leave times no less than 3 years. It is essential to scarify the upland mineral soil sites, but scarification of lowland sites is not recommended, especially where there is abundant Sphagnum.

\section{Résumé}

Dans le mode de régénération par coupes rase en bandes alternées, les principaux facteurs de régénération de l'épinette noire des hautes terres, dans les bandes de première coupe, sont la largeur de ces dernières, la période d'ensemencement naturel, l'étendue réceptive du lit de germination ainsi que la position topographique. Dans les trois peuplements étudiés, les bandes coupées qui avaient $80 \mathrm{~m}$ de largeur ont été occupées à $60 \%$ par plus de 7500 semis à l'hectare après une période d'ensemencement naturel de quatre ans. Dans les bandes de 40 et $20 \mathrm{~m}$ de largeur, la reproduction a été en croissant. La régénération naturelle a été meilleure après quatre années que deux. La densité et le nombre de semis dans les quadrats ont été corrélés à l'étendue réceptive des lits de germination. La régénération était plus abondante dans les chenaux d'écoulement et au bas des pentes qu'au haut des pentes et sur les croupes. Pour assurer la régénération dans des conditions climatiques et physiographiques similaires, la largeur des bandes ne devrait pas dépasser $80 \mathrm{~m}$, et l'intervalle entre les coupes ne devrait pas être inférieure à 3 années. II importe de scarifier les stations élevées à sol minéral, tandis que la scarification des stations basses n'est pas recommandée, notamment lorsque les sphaignes y abondent.

\section{Introduction}

It is becoming increasingly apparent to forest managers in Ontario that it will not be possible to regenerate artificially all the area that is being harvested annually, as the level of funding and resources required will never be reached with the current emphasis on reduction of government spending. Hence, the strategy of intensive management of 'prime sites' has become generally accepted. Most of the regeneration effort and resources will be devoted to the better sites that are close to roads and mills. The poorer sites will be regenerated by less expensive methods, such as direct or natural seeding, or will simply be left after harvesting to develop whatever comes in naturally. It is thus important to develop knowledge and techniques of natural regeneration that are cheap and effective to apply to the poorer and less accessible sites, so that as much land as possible is kept productive.

Canadian Forestry Services, Great Lakes Forestry Centre, P.O. Box 490, Sault Ste. Marie, Ontario P6A 5M7.
There is a large body of literature on strip clearcutting in North America, but a thorough literature review is not within the scope of this paper. The excellent guidelines for black spruce management in Ontario (Robinson 1974) and in the north central United States (Johnston 1977), and the detailed research studies of van Nostrand (1971) in Newfoundland and Frisque (1977) and Frisque and Vezina (1977) in Quebec must be mentioned. It is regrettable that more of the results of this research have not been incorporated into actual practices and procedures. As Frisque (1977) notes: "Many of the conclusions of this thesis only repeat those that excellent foresters have already made in the last 50 years. It is time to pass from the develupment stage and to apply on-the-ground knowledge acquired in research on black spruce." [Translation from the French text.]

One of the first well documented trials of strip cutting in northern Ontario was conducted at the Abitibi Woodlands Laboratory at Raith, west of Thunder Bay, Ontario (Losee 1966). The study showed that the strip-group method can be 
applied successfully to obtain regeneration, and that compaction of the mossy humus layer improves stocking and density of black spruce seedlings. Hughes (1967) conducted a study of white spruce and fir reproduction in the 'mixedwood slope type' near Manitouwadge in north central Ontario, very close to the Nipigon area, and included studies of alternate strip cuts. He reported that regeneration can be obtained by scarification in clearcut strips up to $120 \mathrm{~m}$ wide, but these results were for white spruce and balsam fir.

In the boreal forest of Ontario alternate strip clearcutting has had limited application, but it has been applied mainly to black spruce on shallow-soil uplands and on organic soils. That the levels of natural black spruce regeneration in strip cuts are significantly higher than those in larger clearcuts has been well documented (e.g., Fraser et al. 1976). However, desirable levels of regeneration are not always achieved with strip cutting, and factors such as poor seed supply, several years of dry weather, and poor site preparation may explain failure or marginally acceptable levels of regeneration. Successful application of the method requires a full appreciation of seed supply and seedbed requirements for black spruce seedling germination and growth, and utilization of this knowledge in developing the technical details of strip layout, harvesting and site preparation.

The main ecological factors influencing natural regeneration of black spruce are seed supply, amount and distribution of receptive seedbed, and moisture conditions of the seedbed (cf. Roe et al. 1970). In strip cutting, the residual strips provide the seed for the first-cut strips, and reduce the rate of drying of seedbeds between rainfalls. In applying strip cutting the manager can influence these factors by careful selection and control of the strip widths, natural seeding period (leave time of second cuts), amount and distribution of receptive seedbed, and strip orientation. The choice of strip width will be influenced by the relative amounts of upland and lowland in the area to be strip cut.

A long-term experiment has been in progress since 1974 to document natural regeneration in the first-cut strips of an alternate strip clearcut in black spruce forests (Jeglum 1980). The study area is near Nipigon and Beardmore in north central Ontario (Fig. 1). The study was designed mainly to investigate the influence of strip width and of natural seeding period. ('Seeding period' as used in this paper is the same as 'leave period' for the second-and final-cut strips.) As well, two other critical factors influencing the regeneration - seedbed and topographic site position - were included in the study.

Several reports on the Nipigon strip-cut study have already been published. These deal with natural regeneration of all species in the first-cut strips (Jeglum 1982), changes in proportions of tree species in the regenerating strips (Jeglum 1983), and the relationship of receptive seedbed to regeneration (Jeglum 1984). The purpose of this paper is to highlight some of the key factors influencing the regeneration of black spruce, and to make recommendations to the forest manager on how to achieve successful results with alternate strip clearcutting. It is emphasized that the main factors controlling natural regeneration of black spruce in the first-cut strips are strip width, seeding period (leave time until the second, final-cut strips), amount and distribution of receptive seedbed, and the proportions of upland to lowland conditions.

\section{Study Area and Site Description}

The study area is situated in Site Region 3W (Hills 1960) and in the Central Plateau Section, B.8, of the Boreal Forest

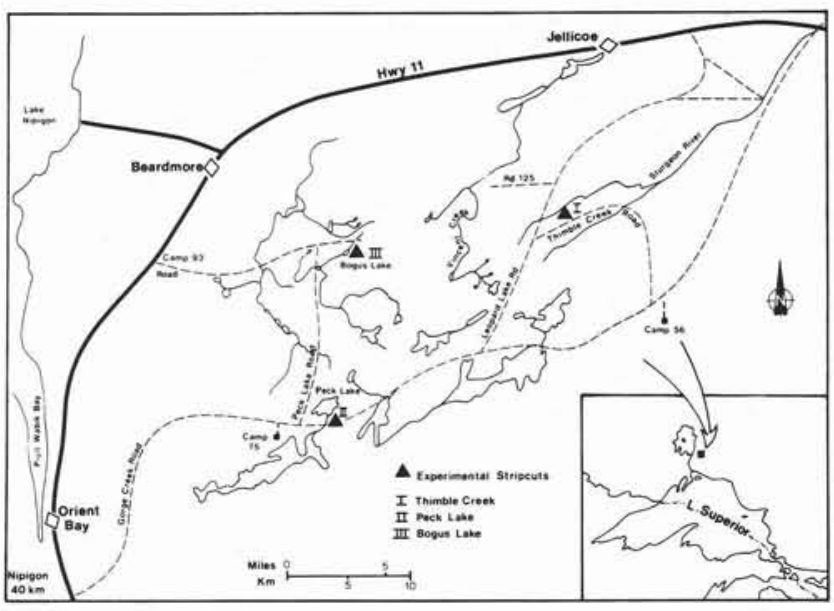

Figure 1. Location of the study area.

Region (Rowe 1972). The area has been described previously in detail (Jeglum 1980). The forests are mostly pure black spruce, or black spruce with small proportions of jack pine, white birch and trembling aspen. Mean ages and heights of dominant black spruce were 113 years (in 1974) and $17.2 \mathrm{~m}$ (14.0-19.9 m), 108 years (in 1975) and $18.7 \mathrm{~m}(15.4-22.5 \mathrm{~m})$, and 123 years (in 1976) and $17.5 \mathrm{~m}(13.1-21.0 \mathrm{~m}$ ) for areas I to III, respectively (Jeglum 1980). Mean site indices were 10.4, 12.0 and $10.3 \mathrm{~m}$ at 50 years for areas I to III, respectively (Plonski 1974). The stands were overmature and densities were 938,1265 , and $1123 \mathrm{~m} / \mathrm{h}$ h for areas I to III, respectively.

The forest floor was mainly a continuous carpet of Schreber's feathermoss overlying an acid mor mat, with pockets of Sphagnum in the drainageways and on lower slopes, and some broadleaf litter and herb-rich areas beneath scattered trees or clumps of birch or aspen.

The study was replicated in three areas within $30 \mathrm{~km}$ of each other (Fig. 1), all with shallow soils over bedrock. The highly variable topography included bedrock ridges and shelves with little or no mineral soil. Soils were mostly stony tills with textures of the matrix predominatly silt to very fine sand. In some places the areas were patterned, with low bedrock ridges alternating with swampy, peat-filled depressions or drainageways. Although the study areas had shallow soils, they were on average somewhat deeper than those considered 'fragile sites' by Flowers and Robinson (1979) in which mineral soils $30 \mathrm{~cm}$ deep or less occupy over $40 \%$ of the area. Currently, a program of forest ecosystem classification is defining shallow-soil ecosystems more precisely (Sims and Towill 1988).

The sites in the experimental areas included a broad range of moisture conditions from wet to dry. Each quadrat was assigned to one of four moisture-related topographic site types: crest, upper slope, transitional (lower slope) and drainageway (Fig. 2, cf. Fraser et al. 1976). Of the three areas, Area II was the moistest, Area III the driest, and Area I intermediate in overall moisture condition.

\section{Methods}

\section{Layout, Harvesting and Site Preparation}

The layout of the strips was generally north-south. Conventional cut and skid havesting was generally used. 


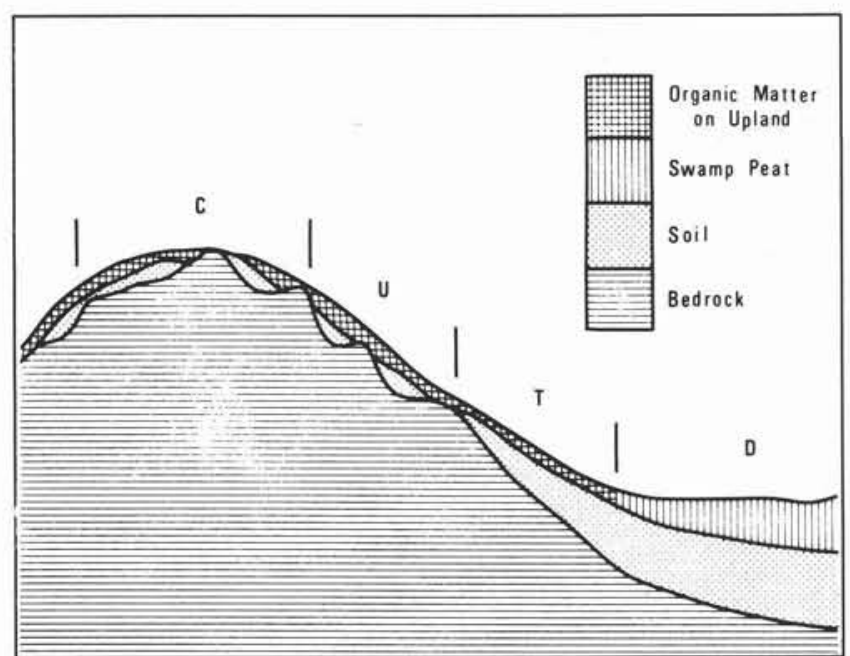

Figure 2. Conceptual model showing four site types in the Nipigon area: $\mathrm{C}$ - crest; $\mathrm{U}$ - upper slope; $\mathrm{T}$ - transitional (lower slope); and D - drainageway

Delimbing and topping were done on site. Standard rubbertired skidders dragged tree-length boles to roadside (Jeglum 1980). Slash was well distributed over the cutover. (This can reduce the effectiveness of scarification and hence the amount of regeneration.)

Areas I and III were cut in the summer, but Area II was considered sufficiently wet to necessitate cutting in winter. Area I was scarified with flanged barrels and anchor chains drawn by large wheeled skidders; Areas II and III were scarified with a TTS-35 Disc Trencher drawn by a skidder. The quality of scarification was consistent with the operational standards of the day since the strip cuts were part of larger contracts for general scarification.

\section{Experimental Design}

The main factors studied were strip width, leave time (length of time between the first and second cuts), and the effects of scarification. As additional factors, the influence of topographic site location, position of the sample quadrats in relation to forest edge, and prescribed burning as a method of site preparation for the first-cut strips were investigated.

The main treatment combinations for first-cut strips were as follows:

1. 20-m, 2-yr, scarified - strips $20 \mathrm{~m}$ wide, with 2-yr natural seeding period, and scarified:

2. 20-m, 4-yr, scarified - as above;

3. 40-m, 2-yr, scarified;

4. 40-m, 4-yr, scarified;

5. 80-m, 2-yr, scarified;

6. 80-m, 4-yr, scarified;

7. 40-m, 2-yr, nonscarified (control).

Each of the above treatments was represented by four strips. Hence, there were 28 first-cut strips and 28 second-cut 'leave' strips in each area. The layout of the strips was such that strips of each of the widths were in blocks to facilitate laying them out and to avoid confusion during harvesting.

Scarification of the strips was the main prescription, but four 40-m-wide unscarified controls were included for comparison. These controls were scheduled to receive 2 years of natural seeding, the operational prescription at that time.

A systematic grid of 25 quadrats, each $2 \mathrm{~m}^{2}$, was used to sample each strip. An additional 50 quadrats were placed in each nonscarified strip later in the study to obtain a better sample of the nonscarified condition. Hence, the total number of quadrats in the first-cut strips in each area was 900.

For each strip, five quadrats occurred in each of five equidistant strip locations in relation to the north-south axis of the strips. This allowed an assessment of the effect of proximity to seed source in the leave strips on regeneration in the first-cut strips.

In this paper, the term 'seedlings' is used for all individuals $>2.5 \mathrm{~cm} \mathrm{DBH}$. This study did not separate advance growth seedlings from those originating after harvesting.

Total percentage of 'receptive seedbed' was derived for each quadrat on the basis of a detailed analysis of the relationships of black spruce seedlings to ground surface materials (Jeglum 1984). Receptive seedbed is the sum of the individual cover estimates of all subsurface soil horizons that have been exposed by harvesting disturbance and scarification, plus mosses that either retain moisture very well (Sphagnum) or have colonized the disturbed surfaces (pioneer mosses).

In the analysis of topographic relationships, crest and upper slope were combined into 'upland', and transitional and drainageway were combined into 'lowland'.

A special study of prescribed burning was conducted in two of the unscarified strips in Area III to determine the effectiveness of fire as site preparation to produce receptive seedbed for natural regeneration. The first burn was conducted in 1978 and received 3 years of natural seeding; the second burn was conducted in 1979 and received 2 years of natural seeding.

\section{Results and Discussion}

\section{Strip Width}

Adequate stocking levels were achieved with cut strips up to $80 \mathrm{~m}$ wide and a 4 -yr seeding period (Table I). Densities after 4 years of seeding ranged from 7500 per ha in the $80-m$ strips of Area I to 29500 per ha in the 20-m strips of Area II (Table 2). The latter densities are too high, and juvenile stand spacing would be required to obtain optimal stand development. This suggests that there is an optimum strip width and site preparation combination for achieving desirable stocking without excessive densities of seedlings.

Table 1. Stocking percentage (frequency) of black spruce seedlings in relation to strip width and seeding period. ${ }^{1}$

\begin{tabular}{ccccc}
\hline & Seeding & \multicolumn{3}{c}{ Strip width (m) } \\
\cline { 3 - 5 } Area & period $^{2}$ & \multicolumn{1}{c}{$\mathbf{2 0}$} & \multicolumn{1}{c}{$\mathbf{4 0}$} & \multicolumn{1}{c}{$\mathbf{8 0}$} \\
\hline I & $2-\mathrm{yr}$ & $51(100)^{3}$ & $50(100)$ & $52(100)$ \\
& $4-\mathrm{yr}$ & $69(100)$ & $62(65)$ & $63(100)$ \\
II & $2-\mathrm{yr}$ & $77(100)$ & $67(99)$ & $58(85)$ \\
& $4-\mathrm{yr}$ & $89(87)$ & $72(97)$ & $62(100)$ \\
III & $2-\mathrm{yr}$ & $42(100)$ & $50(125)$ & $43(100)$ \\
& $4-\mathrm{yr}$ & $78(100)$ & $49(75)$ & $63(100)$ \\
\hline
\end{tabular}

Data from all scarified strips; seedlings are stem $>2.5 \mathrm{~cm} \mathrm{DBH}$.

2'Seeding period' for first-cut strips also means 'leave period' for second cut strips.

${ }^{3}$ Number of $2 \times 2-m$ quadrats. 
Table 2. Mean density of black spruce seedlings in relation to strip width and seeding period. ${ }^{1}$

\begin{tabular}{|c|c|c|c|c|}
\hline \multirow[b]{2}{*}{ Area } & \multirow{2}{*}{$\begin{array}{l}\text { Seeding } \\
\text { period }^{2}\end{array}$} & \multicolumn{3}{|c|}{ Strip width (m) } \\
\hline & & 20 & 40 & 80 \\
\hline \multirow[t]{2}{*}{1} & $2-y r$ & 4.25 & 8.75 & 7.50 \\
\hline & $4-y r$ & 13.50 & 10.00 & 7.50 \\
\hline \multirow[t]{2}{*}{ II } & $2-y r$ & 15.75 & 10.25 & 7.25 \\
\hline & $4-y r$ & 29.50 & 16.25 & 11.25 \\
\hline \multirow[t]{2}{*}{ III } & $2-y r$ & 10.25 & 8.00 & 4.00 \\
\hline & $4-y r$ & 21.50 & 9.00 & 13.25 \\
\hline
\end{tabular}

IMeans are in seedlings per ha $\times 10^{-3}$ : Table 1 gives the quadrat numbers on which they are based. Data from all scarified strips.

${ }^{2}$ 'Seeding period' for first cut strips also means 'leave period' for second cut strips.

With $80-m$ strips, the numbers of seedlings were slightly lower in the strip centres, although stocking remained the same. A strip width of $60 \mathrm{~m}$ seems to be optimum, at least for the Nipigon study area and for the standard level of operational site preparation. This may apply to other areas with similar physiographic, site and climatic conditions, but the optimum strip width will probably be somewhat wider in more humid regions, and somewhat narrower in drier climates.

\section{Seeding Period (Leave Period)}

For most strip width comparisons, stocking and density were higher after 4 years of natural seeding than after 2 years (Tables 1 and 2). For areas I and III, the two drier areas, the levels of stocking after 2 years of seeding (between $42 \%$ and $52 \%$ ) were in the marginally acceptable range (cf. Robinson 1974). After 4 years, the levels were mostly above $60 \%$ (Table 1 ). This suggests that 2 years of seeding are insufficient, and that 3 or 4 years are more likely to provide desirable stocking levels. This finding contrasts with that of Verry and Elling (1978) that 2 years are enough. However, their study was conducted in a black spruce swamp type that was, on average, moister than the Nipigon shallow-soil sites. Therefore, leave period should not be considered an absolute, and for any particular strip-cut operation it may be longer or shorter depending on the specific set of site conditions, the amount of receptive seedbed, the seed supply, and the weather conditions.

There is some evidence that natural regeneration occurs mainly on freshly disturbed surfaces, and that after a number of years disturbed surfaces mature and become less receptive (Jeglum 1984). This is particularly true for exposed upland humus, which develops an unreceptive, crusty lichen surface. As well, pioneer mosses provide a receptive seedbed for the first few years after they colonize disturbed surfaces. Later these mosses may become less receptive as they develop into thicker and drier mats. Ultimately, the manager must decide how long to wait for regeneration, but if acceptable regeneration has not occurred by the fifth year after cutting, further regeneration measures should be taken

\section{Receptive Seedbed}

Receptive seedbed means on scarified quadrats in Areas I, II, and III were $21 \%, 29 \%$ and $31 \%$, respectively. The lesser amounts of receptive seedbed in Area I were probably owing to the different methods of scarification - with flanged barrels in area I and with the TTS Disc Trencher in Areas II and III.

As noted previously, for each of the three replicated study areas, the 4-year seeded $80-\mathrm{m}$ strips achieved over $60 \%$ stocking (Table 1). This suggests that about 20 to $25 \%$ mean receptive seedbed is necessary to achieve $60 \%$ stocking to black spruce in an 80-m strip width. Similar levels of scarification in narrower strips will result in higher regeneration levels.

Seedling stocking and density were calculated for five percentage classes of receptive seedbed: 0,0 to 5,5 to 15,15 to 35 , and $35 \%$ (Table 3 ). There were distinct differences among these classes for 20-m, 40-m, and 80-m strips widths. As the amount of seedbed increased, so did the regeneration. The levels of stocking and density were generally highest for the $20-\mathrm{m}$ strips and decreased on the $40-\mathrm{m}$ and $80-\mathrm{m}$ strips. This is related to decreasing seed supply and increasing exposure from narrower to wider strips.

There is an interaction between the amount of receptive seedbed required and the width of strips. For example, the $60 \%$ stocking level is achieved in the 20 -m strips for the $>0$ to $5 \%$ receptive seedbed class, in the $40-m$ strips for the $>5$ to $15 \%$ receptive seedbed class, and in the $80-\mathrm{m}$ strips for the $>15$ to 35 receptive seedbed class (Table 3 ). This suggests that, as strips become wider, the manager may achieve acceptable levels of regeneration by increasing the intensity of scarification to provide more receptive seedbed. Conversely, for narrower strips less intense scarification is required.

\section{Topographic Position}

Regeneration is clearly better on lowlands than on uplands (Table 4). Hence, the manager may regulate strip width according to the proportion of broad mositure-related topographic positions of lowland and upland. If drier uplands predominate, the manager might consider using 40-m strips; if wet lowlands predominate, he can probably use $80-\mathrm{m}$ strips and achieve adequate regeneration. Verry and Elling (1978) suggested that widths in Minnesota be no more than $120 \mathrm{~m}$ for nonbrushy black spruce swamps.

Table 3. Stocking (S) and density (D) of black spruce seedlings in relation to five classes of receptive seedbed in 20-m, $40-\mathrm{m}$ and $80-\mathrm{m}$ strips. ${ }^{1}$

\begin{tabular}{|c|c|c|c|c|c|c|c|c|c|}
\hline \multirow{3}{*}{$\begin{array}{l}\text { Receptive } \\
\text { seedbed } \\
\text { classes } \\
(\%)\end{array}$} & \multicolumn{9}{|c|}{ Strip width } \\
\hline & \multicolumn{3}{|c|}{$20-m$} & \multicolumn{3}{|c|}{$40-\mathrm{m}$} & \multicolumn{3}{|c|}{$80-m$} \\
\hline & $\mathbf{n}$ & S & D & $\mathbf{n}$ & $\mathbf{S}$ & D & $\mathbf{n}$ & $\mathbf{S}$ & D \\
\hline \begin{tabular}{l}
\multicolumn{1}{c}{0} \\
0 to 5 \\
5 to 15 \\
15 to 35 \\
35 \\
All
\end{tabular} & $\begin{array}{r}15 \\
52 \\
47 \\
80 \\
93 \\
287\end{array}$ & $\begin{array}{l}47 \\
67 \\
68 \\
85 \\
88 \\
78\end{array}$ & $\begin{array}{r}4.25 \\
11.00 \\
9.75 \\
17.00 \\
38.75 \\
21.00\end{array}$ & $\begin{array}{r}7 \\
41 \\
38 \\
36 \\
40 \\
162\end{array}$ & $\begin{array}{l}14 \\
47 \\
60 \\
60 \\
81 \\
62\end{array}$ & $\begin{array}{c}+ \\
5.00 \\
6.00 \\
13.75 \\
22.75 \\
12.25\end{array}$ & $\begin{array}{r}5 \\
53 \\
47 \\
99 \\
96 \\
300\end{array}$ & $\begin{array}{l}40 \\
45 \\
55 \\
65 \\
75 \\
63\end{array}$ & $\begin{array}{r}3.50 \\
4.50 \\
6.25 \\
11.00 \\
16.00 \\
10.50\end{array}$ \\
\hline
\end{tabular}

Mean densities are in seedlings per hectare $\times 10^{-3}$. Data from all scarified, 4-year seeded strips in all areas. 
Table 4. Receptive seedbed and seedling stocking in relation to strip width and topographic position.

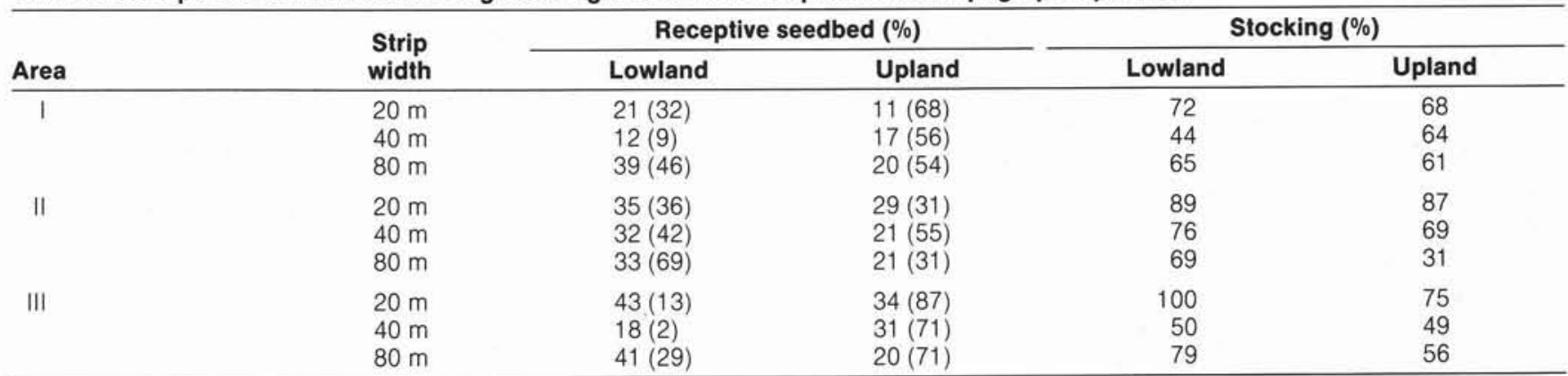

Unscarified (all areas)

$40 \mathrm{~m} \quad 16(385)$

$12(320)$

61

38

1Lowland represents drainageways and transitional lower slopes, and upland represents upper slopes and crests. Data from 4-year old seeded strips, except for unscarified, unburned controls which include 2-year and 4-year seeded strips. Numbers of quadrats are in parentheses.

There was usually more receptive seedbed on lowlands than on uplands (Table 4) and, consequently, black spruce stocking was usually higher on the former than on the latter. The smallest differences in stocking between lowlands and uplands were for the 20-m strips. As strip widths increased, stocking decreased more rapidly in uplands than in lowlands. For the 80-m strips, the levels of stocking for lowlands ranged from $65 \%$ to $79 \%$, but for the uplands the levels ranged from $31 \%$ to $61 \%$. This suggests that strips should be narrower for upland than for lowland sites to achieve comparable regeneration levels.

The nonscarified and scarified strips showed similar relationships to topographic position (Table 4). Overall stocking in the lowlands was $61 \%$, whereas in the uplands it was only $38 \%$. Thus if an area is predominantly lowland, it may not require scarification when strips are $40 \mathrm{~m}$ wide, and if an area consists of a mosaic of site conditions, it may be possible to scarify only the upland portions, thereby saving time and money

\section{Site Preparation}

Proper site preparation is the key to obtaining successful regeneration. It is important to achieve optimum distribution of receptive seedbed, enough to achieve desirable levels of stocking but not so much that the seedlings are too numerous. Hence, it is suggested that the row trencher or patch scarifier is best for providing good distribution of seedbed but with moderate areas of receptive seedbed.

Areas of Sphagnum in both scarified and nonscarified strips frequently had excellent regeneration, consisting of both natural seedlings and advance growth. For this reason, it is suggested that the Sphagnum should not be scarified since it is already an excellent receptive seedbed. Frisque and Vezina (1977) also suggested that on wet sites it is useless to prepare the ground to improve natural black spruce regeneration. In planning site preparation, one should devise methods whereby the Sphagnum areas are delineated and not scarified. These areas could be bypassed by lifting the scarification device, and/or driving around it on firmer ground if possible. It would be useful to test various low ground pressure techniques - e.g., crawlers, wide-tired skidders, and metal tracks fitted around rubber tires - that would lessen the bearing pressure on the ground and reduce rutting on wet, peaty sites.
Prescribed burns were conducted in two strips in Area III. These burns did not provide good site preparation because of low consumption of the organic duff and considerable ash surface that became very dry on the upland portions of the strips. Hence, stocking was very low (32\%) and the regeneration that did occur was in the wet, low spots where Sphagnum was abundant. The poor removal of duff from the uplands may have been owing to the low-to-moderate fire indices at the time of the burns. Moreover, the burns required much supervision and were very expensive in relation to their small extent. It was concluded that prescribed burning should not be used as a site preparation tool for natural regeneration of black spruce in strip cuts on shallow-soil uplands.

This study also suggests that it may not be necessary to scarify lowland sites to obtain satisfactory regeneration. Nonscarified, $40-\mathrm{m}$ strips achieved over $60 \%$ stocking in the quadrats classifed as lowland (Table 5 ). If the site type is predominantly lowland and has a high proportion of Sphagnum, 40-m strip widths might provide satisfactory regeneration without site preparation. However, in many black spruce areas mosaics of lowland and upland occur, with wetter and drier areas. Without scarification the manager may expect to obtain marginal regeneration on the higher, drier parts that are often dominated by feather-moss. In these circumstances, he could increase the chances for successful regeneration by narrowing the strip widths to $30 \mathrm{~m}$ and by employing full-tree logging to minimize slash, which inhibits regeneration.

With thorough scarification or abundant Sphagnum, excessively high densities of natural regeneration may occur. In this study, both 20-m and 40-m strips achieved over 15000 seedlings pr ha in the 15 to $35 \%$ receptive seedbed class. This is considered excessively dense, and it is more important to increase stocking than density. Hence, the manager should apply site preparation treatments that obtain an optimum frequency of small scarified spots or strips (cf. Frisque and Vezina 1977). This may be best achieved by regulating spacings between the trenches of a disc trencher, or between the patches created by a patch scarifier.

\section{Other Considerations}

This study dealt only with a layout of equal widths for firstand second-cut strips. The first-cut strips could be wider than the second cuts, to obtain more natural regeneration in the 
first cut and have less second-cut area to regenerate with other possibly more expensive methods (Jeglum 1982). In fact, an 80 - to $60-\mathrm{m}$ ratio was recently tried by Domtar, but it was decided that using equal strip widths was preferable for planning, layout, and provision of a more balanced wood supply from the two harvests. A progressive strip system with three or more cuts could also be applied to achieve a higher proportion of naturally regenerated land, but this approach has been used infrequently in Ontario.

It must be ascertained before strip cutting that there are enough recent cones containing viable seed in the forest to be strip cut. Cone numbers should be assessed and cone collections sent to specialists for seed counts and viability tests. Knowing seed-year periodicity would also be useful. However, it is probably not necessary to coordinate strip cutting precisely with a heavy cone year, because black spruce has semi-serotinous cones that retain viable seed in the crowns (Haavisto 1980), and the seedfall is spread out over a number of years.

In this study, it was not attempted to classify the origin whether from layers or from seed - of all the seedling-size individuals, or to differentiate between regeneration established before and after harvesting. However, in the postharvest, post-scarification assessments, the origin of individuals in the lowest height class was recorded. The results suggested that the majority of all seedlings originated form seed after the harvest. Frisque and Vezina (1977) reported that layers accounted for half the black spruce reproduction 5 years after strip cutting. Their sites were wet, with fibrous peaty mor 10 to $38 \mathrm{~cm}$ thick and abundant Sphagnum as seedbed.

All strips were oriented north-south in this study to achieve good dispersal of seed across the strips by prevailing westerly winds. The available resources did not permit inclusion of other strip orientations. Actually, the prevailing strong winds are common from S to SW to W. Theoretically, a SE-NW strip orientation would provide the best seed dispersal, as well as better protection from solar radiation during the hottest part of the day (early to mid-afternoon). An east-west orientation would provide shade to the south side of the strips, but might not result in as good seed dispersal.

Whenever there are some hardwoods in the original stand there is a potential problem of competition (Jeglum 1982). This problem is also encountered in clearcutting, but strip clearcutting may favor somewhat higher levels of regeneration from the seed of broad-leaved trees that may be present in the residual strips. Hardwood control may be necessary at an early stage of the juvenile stand development.

Another problem encountered in this study was that during the second cut the skidders often passed through the regenerated first-cut strips damaging some of the regeneration. This practice should be discouraged. However, if the final cut is done when there is a protective cover of snow on if high-flotation tires are used, some modest degree of travel over the regenerated strips may be acceptable.

Strip cutting may be used to preserve genetic variability and to establish seed production areas in good-quality black spruce stands. There are old strip cuts near Area II (Jean Lake strips) in which the first-cut strips (30 m wide) achieved $100 \%$ stocking and very high densities. The second-cut strips (15 m wide) achieved between 50 and $60 \%$ stocking. This area has been thinned and turned into a seed production area.
Progressive strip cutting has been undertaken in the Wawa area of Ontario for the same reason, to preserve genetic stock. $^{2}$

\section{Recommendations}

1. Employ strip cutting in stands dominated by black spruce or black spruce/jack pine. Usually the technique should be applied on poorer, environmentally sensitive sites especially shallow-soil sites and poor organic soil sites, and sites that have poor access or are far from the mill.

2. If there is significant aspen or white birch in the original forest, regeneration levels of these species will be high, and it may be necessary to control broadleaf competition early to favor black spruce and jack pine.

3. Do not employ strip cutting unless moderate numbers of recent cones with viable seed are still present.

4. For physiographic-climatic conditions similar to those at Nipigon, use strips no wider than $80 \mathrm{~m}$, preferably $60 \mathrm{~m}$ for safety.

5. Retain leave strips from 3 to 5 years before harvesting. Conduct a regeneration survey at year 3 to determine whether regeneration is acceptable.

6. Site prepare the first-cut strips as soon as possible after the harvest to provide receptive seedbed. Site preparation should provide small patches or narrow strips of receptive seedbed with somewhat closer spacing than would normally be provided for tree planting.

7. Do not site prepare lowlands that have abundant sphagnum moss or advance growth. Sphagnum is already an excellent receptive seedbed, and site preparation may reduce the Sphagnum, create deep wheel ruts and wet mucky patches, and destroy existing advance growth.

8. Conduct a study of site preparation tools and highflotation equipment applied to strip cutting to determine costs, efficiency, and biological effectiveness.

9. Employ full-tree logging to remove slash and improve effectiveness of scarification. However, if there is much jack pine in the stand, use a tree-length system plus scarification to favor jack pine regeneration from cones in the slash left on site.

10. Do not use prescribed burning for site preparation in shallow-soil upland strip cuts. This will not provide sufficient receptive seedbed, will often destroy advance growth, and is not economical on individual strips with small areas.

11. Do not run machines through the regenerated strips when harvesting the second (final) cuts.

\section{Acknowledgments}

I gratefully acknowledge N. Carl and P.L. Copis for laying out the experimental areas; KBM Forestry Consultants Inc., Dames and Moore, Crossfield Environmental Ltd., and Matcam Forestry

${ }^{2}$ G.T. Atkinson, Great Lakes Forestry Centre, personal communication. 
Consultants Inc. for field data collection; P.L. Copis and S.J. Taylor for data management; D.W. Beilhartz and N. Bailey for assistance in data analysis; and A. Groot and V.F. Haavisto for reviewing the manuscript. I also thank J.W. Fraser and G.T. Marek for direction and advice in designing and conducting the study.

\section{References}

Flowers, J.F. and F.C. Robinson. 1979. Proposed policy for controlling the size of clearcuts in northern forest regions of Ontario. Ont. Min. Nat. Resour., Toronto, Ont. 30 p.

Fraser, J.W., V.F. Haavisto, J.K. Jeglum, T.S. Dai and D.W. Smith. 1976. Black spruce regeneration on strip cuts and clearcuts in the Nipigon and Cochrane areas of Ontario. Dep. Environ. Can. For. Serv., Sault Ste. Marie, Ont. Report O-X-246. 33 p.

Frisque, G. 1977. Régénération naturelle de l'épinette noire (Picea mariana [Mill.] B.S.P.). Ph.D. Thesis, Laval Univ., Quebec. $546 \mathrm{p}$.

Frisque, G. and P.E. Vezina. 1977. Reproduction of black spruce (Picea mariana [Mill.] B.S.P.) following small clear-cuttings. Can. J. For. Res. 7: 648-655

Haavisto, V.F. 1980. The retention of seed viability in semi-serotinous black spruce cones. p. 91-95 in Proc. IUFRO Internat'I. Symp. For. Tree Seed Storage. Dep. Environ., Can. For. Serv., Chalk River, Ont., 23-27 Sept. 1980.

Hills, G.A. 1960. Regional site research. For. Chron. 36: 401-423.

Hughes, E.L. 1967. Studies in stand and seedbed treatment to obtain spruce and fir reproduction on the mixedwood slope type of northwestern Ontario. Can. Dep. For. Rur. Devel., For. Br., Dep. Publ. No. 1189.138 p.

Jeglum, J.K. 1980. Strip cutting in shallow-soil upland black spruce near Nipigon, Ontario. I. Study establishment and site conditions. Dep. Environ., Can. For Serv., Sault Ste. Marie, Ont. Report O-X-315.61 p. + appendices.

Jeglum, J.K. 1982. Strip cutting in shallow-soil upland black spruce near Nipigon, Ontario. II. Regeneration in the first study area.
Dep. Environ., Can. For. Serv., Sault Ste. Marie, Ont. Inf. Rep. O-X-336. $24 \mathrm{p}$

Jeglum, J.K. 1983. Changes in tree species composition in naturally regenerating strip clearcuts in shallow-soil upland black spruce. p. 180-193 in R.W. Wein, R.R. Riewe, and I.R. Methven, Ed., Proc. 'Resources and dynamics of the boreal zone', Thunder Bay, Ont. Aug. 1982. Assoc. Can. Univ. North. Stud.

Jeglum, J.K. 1984. Strip cutting in shallow-soil upland black spruce near Nipigon, Ontario. IV. Seedling-seedbed relationships. Dep. Environ., Can. For. Serv., Sault Ste. Marie, Ont. Inf. Rep. O-X-359. $26 \mathrm{p}$.

Johnston, W.F. 1977. Manager's handbook for black spruce in the north central States. USDA For. Serv., St. Paul, Minn. Gen. Tech. Rep. NC-34. $18 \mathrm{p}$

Losee, S.T.B. 1966. Strip group cutting in black spruce at the Abitibi Woodlands Laboratory. Can. Pulp. Pap. Assoc., Pulp Pap. Mag. Can., June 1966. WSI 2b70(F-2). 5 p.

Plonski, W.L. 1974. Normal yield tables (metric). Ont. Min. Nat. Resour., Div. For. 40 p.

Robinson, F.C. 1974. A silvicultural guide to the black spruce working group. Ont. Min. Nat. Resour., Div. For., Mange. Br. $44 \mathrm{p}$.

Roe, A.L., R.R. Alexander and M.D. Andrews. 1970. Englemann spruce regeneraiton practices in the Rocky Mountains. USDA For. Serv., Prod. Res. Rep. 115. 32 p.

Rowe, J.S. 1972. Forest regions of Canada. Dep. Environ., Can. For. Serv., Ottawa, Ont. Publ. No. 1300.172 p.

Sims, R.A. and W.D. Towill. 1988. Alternate strip clearcutting in upland black spruce. VIII. Shallow-soil ecosystems and their classification. For. Chron. 64 (In press).

van Nostrand, R.S. 1971. Strip cutting black spruce in central Newfounđland to induce regeneration. Can. For. Serv., St. John's, Nfld., Publ. No. 1294. 21 p.

Verry, E.S. and A.E. Elling. 1978. Two years necessary for successful natural seeding in nonbushy black spruce bogs. USDA For. Serv., St. Paul, Minn. Res. Note NC-229. 3 p.

\title{
THE INTERNATIONAL FORESTRY CONFERENCE FOR THE AUSTRALIAN BICENTENARY
}

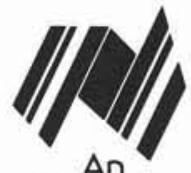

An

Endorsed

Bicentennial Activity

\author{
celebrating
}

\section{YEARS OF AUSTRALIAN FORESTRY}

The species and their contribution to

Australia and the World,

Past, Present and Future.

25th April - 1st May 1988

Albury-Wodonga/N.S.W.-Vic., Australia

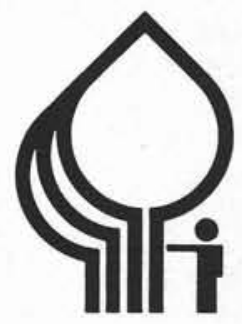

More than 100 speakers will share their knowledge of Eucalypts, Acacias and harvesting, native species, silviculture, fuel, Casuarinas, and species introduced into Australia. Subjects under discussion include trees on farms, utilisation studies, commercial forestry, economics and wood and practical forestry. Two full field day tours are included with inspections of Eucalypt, Cypress pine and radiata production forestry, protection and agroforestry.

\section{SPECIAL HIGHLIGHT - THE PRESENTATION OF THE QUEENS AWARD FOR FORESTRY}

For a warm welcome to Canadians contact:

Mr. Bob Newman, Conference Secretary, AFDI Forestry Conference

P.O. Box 802, Albury, N.S.W. 2640, Australia

Telephone: National (060) 41 1266, International 61-60-41 1266

Telex: AA58666, Facsimile: National (060) 21 8501, International 61-60-21 8501 